\title{
Radio Listening Habit of Rural Women in Idemili South Local Government Area of Anambra State, Nigeria.
}

\author{
Leo O. N. Edegoh, Ezekiel S. Asemah, Angela N. Nwammuo \\ Department of Mass Communication, Anambra State University, Igbariam Campus, Anambra State, Nigeria, \\ Department of Mass Communication, Kogi State University, Anyigba, Kogi State, Nigeria, \\ (Ph.D), Department of Mass Commutation, Anambra State University, Uli, Anambra State, Nigeria.
}

\begin{abstract}
The potential of radio to inform, educate and entertain its audience, its capacity to break illiteracy barriers as well as its power to penetrate into the remote areas of our rural communities with clear signal is well recognised. What is not known is how often rural people listen to radio and the type of programmes they show interest in; this study investigates radio listening habit of rural women and aimed at finding out how often they listen to radio, the kind of programmes that interest rural women and the gratifications they derive from listening to radio. Anchored on the uses and gratifications theory of the media, the study adopted survey research method and used questionnaire as an instrument of data collection. A total of 740 women drawn from Idemili South Local Government Area formed the sample of the study. Findings of the study show that a good number of rural women listen to radio and that programmes that interest them most are health related and agricultural programmes. The study recommends the utilisation of radio by government and its agencies for disseminating messages intended for rural people.
\end{abstract}

Keywords: Radio, Listing habit, rural women, Idemili South and Anambra State.

\section{Introduction}

Communication is a process of sharing meaning and experience between people (Okunna, 1999,p.72). It is an activity or process that entails mutual sharing or exchange of ideas, information, feelings, emotions and reactions (Unoh, 1991 cited in Okoro and Agbo, 2003). Communication is a critical factor for any meaningful development to take place. This explains why Asemah, Anum and Edegoh (2013, p.18) rightly observe that information is central to all forms of human activity no matter the field, be it medicine, agriculture, tourism or engineering.

Radio is an indispensable medium of communication for achieving development in the rural areas, as issues of development are aired to audience in the form of various programmes and individuals are exposed to happenings in and around their society, through listening to these programmes (Asemah, Anum and Edegoh, 2013). It is believed that radio is the most effective, popular and credible medium for reaching a large and heterogeneous audience. (Nwabueze, 2007, p. 65). Radio communication informs and educates the audience on new issues inherent in the society. For example, issues on politics, business, current affairs, etc., are aired to create awareness. Radio is an agent of social mobilisation capable of galvanising citizens to take certain goals based on their awareness of their rights and responsibility to the society. Based on the numerous potentials of radio in ensuring rural development, it is imperative to examine how people who are the recipients of radio messages react to radio programmes, their radio listening habit and how often they expose themselves to radio programmes. Thus, this paper focuses on radio listening habit of rural women in Idemili South Local Government Area of Anambra State, Nigeria

\section{Problem Statement}

Radio programmes designed for the relaxation, entertainment, information and education of rural audience take substantial air time of radio stations in Anambra State. Such progrmmes which cover agriculture, security, medicine and health, religion and family issues, among others, are disseminated from several radio stations in and around the state such as Anambra Broadcasting Radio, Radio Nigeria, Minaj Radio, and other FM radio stations in the state such as Blaise in Oraifite and Radio Sapiencer in Onitsha. Thus, Anambra State is rich in broadcast media output. What is not known is how the audience receives these programmes, the frequency at which they expose themselves to the programmes, the reasons for exposing themselves to the programmes and the effect of the programmes on the audience. It is this gap that this study intends to fill.

\section{Objectives of the Study}

The following objectives are formulated to guide the conduct of the study: 
i. To find out whether rural women in Idemili South Local Government Area of Anambra State, Nigeria, listen to radio.

ii. To ascertain how often the rural women in Idemili South Local Government Area of Anambra State, Nigeria, listen to radio.

iii. To determine the type of radio programmes that interest the rural women in Idemili South Local Government Area of Anambra State, Nigeria.

iv. To find out the gratifications the rural women in Idemili South Local Government Area of Anambra State, Nigeria, derive from listening to radio programmes.

\section{Research Questions}

In pursuance of the study's objectives, the following questions are posed:

i. Do the rural women in Idemili South Local Government Area of Anambra State, Nigeria,listen to radio?

ii. How often do the rural women in Idemili South Local Government Area of Anambra State, Nigeria, listen to radio?

iii. What type of radio programmes interest the rural women in Idemili South Local Government Area of Anambra State, Nigeria?

iv. What gratifications do the rural women in Idemili South Local Government Area of AnambraState, Nigeria derive from listening to radio programmes?

\section{Theoretical Framework}

Daramola (2003) opines that communication theory is "a set of ideas which provides an explanation for communication phenomena" and Social Philosopher, Abraham Kaplan (1960) cited in Edegoh and Asemah (2013) says that "a theory is a way of making sense out of a disturbing situation. Theories are important in any academic endeavour as they lend themselves to various texts and analysis such that the phenomenon central to the study get explained, clarified and even predicted as the case may be (Asemah, 2010, p.345; Asemah and Edegoh, 2012). Thus, this study finds anchor on the uses and gratification theory of the media.

The uses and gratifications theory of the media is one of the theories of mass communication that call attention to what people do with the media rather than what the media do to people. According to Edegoh, Nwanolue and Eze (2013) the uses and gratification theory was propounded by Elihu Katz, Jay Blumler and Michael Gurevitch in 1974. The theory holds that people influence the effects that mass media have on them (Anaeto, Onabanjo and Osifeso, 2008, p. 71). The assumption of the theory is that people are not just passive receivers of media messages but actively influence the message effects. This is because people selectively choose, attend to perceive and retain mass media messages on the basis of their needs, beliefs, etc. Thus, Anaeto Onabanjo and Osifeso $(2008$, p.71) rightly observe that there are as many reasons for using the media as there are media users. Uses and gratifications theory has a lot of relevance to the present work because it perceives recipients of media offerings as actively influencing the effect process, since they selectively choose, attend to, perceive and retain media messages.

\section{Review of Related Literature}

Radio is a very potent communication medium with unique attribute which make it capable of reaching a wide range of audience simultaneously availing mankind the best means of information dissemination and reception (Acholonu, 2009, p. 61). Radio is seen as the most effective, spontaneous means of communication and an electronic information carrier. Owuamalam (2007, p.2) posits that radio is:

An electronic device which transmits sound signals into the air, at particular frequencies. The radio receiver translates the signals to comprehensive aural messages as intended and provided by the source. It is the fidelity of the radio receiver that ensures clarity in reception and eliminates entropy (noise) which impedes meaning.

The broadcast audio medium of radio is believed to be the most effective, popular and credible medium for reaching a large and heterogeneous audience (Nwabueze, 2007, p. 65). Articulating views on the many benefits of radio as a medium of communication particularly in the rural areas, Asemah, Anum and Edegoh (2013, p.24) assert that radio can be used to mobilize the people at the grassroot level for community development and national consciousness. According to the authors, no serious mass oriented development, especially in rural communities in Africa ever succeeds without the active involvement of the people within the traditional system.

Rural radio programme serves as a source of cultural, political, health and other educational and enlightenment programmes for the masses, leading them towards self-actualization and national development. This probably informs the submission of Okam (1981) cited in Asemah, Anum and Edegoh (2013, p. 25) that much of the failure that attends government mass - oriented programmes are traceable to the fact that policy makers at the national level fail to utilise this powerful and credible medium. 
The potentials of radio can be harnessed to create entertainment through arts and cultural festivals, musicals and dramatic performance, by local singing groups, masquerades and other music and drama groups. Radio is a medium of communication and through it individuals share the world around them and beyond their immediate environment. Thus, it is essential to provide through radio a kind of general education necessary for people to make sound decision about any prevailing social issue in their environment. This is so because as Asemah, Anum and Edegoh (2013) correctly submit that social objective of using radio to mobilise people in Nigeria entails the area of education, information and entertainment.

Radio is a powerful electronic medium that is utilised in bringing political, economic and social news to any community or group of communities faster than other media. In his contribution on the role of radio, Nwuneli, cited in Asemah (2011) says it has brought stimulus into the house, brings about competitions within families, thereby, grooming people who will contribute positively to the process of development. Salama (1978) cited in Asemah, Anum and Edegoh (2013) notes that radio serves as an opinion leader in its news commentary and editiorial. In programmes like drama, radio mirrors the society, presenting issues relevant to society in action which creates easy understanding and learning. Radio informs and educates the listeners in its discussion and documentary programmes. It also entertains in its light programmes like musicals, sports, comedy and dances. It seeks to improve the society in its special occupational programmes geared towards agriculture, business and other related areas.

In essence, radio can be employed to pass across vital information about latest techniques in agriculture, trends in agricultural extension services, etc., to the generality of rural dwellers. The radio is a popular and ubiquitous medium of mass communication and the most pervasive in every part of the world (Okoro, 1998, p. 71). The writer discusses the advantages of radio as follows:

i. Pervasiveness: The radio is not only highly intrusive but also possesses the power to shatter walls of privacy the moment it is on. It possesses a universal attribute which enables it to cut across the barriers of illiteracy and poverty.

ii. Immediacy: The radio has the capacity to relate the events to the audience as it is happening. Okoro (1998) avers that the radio relays signals to the home at the speed of 186,000 miles per second. The radio can also transport the audience to the scene of event while still at home.

iii. Economy: Radio is economical medium in terms of buying radio sets and in terms of programme production, airing and set maintenance.

iv. Flexibility: Replacement of message at the last minute with minimum cost and inconvenience is easy in radio programming. Also radio is flexible in providing specialised programming for varied audience-types.

v. Presence: The human warmth and power of the voice associated with the radio create unseen, near realistic physical presence.

Radio can be employed to pass vital information about the right attitude, behaviour, knowledge, technique and skills, which are expected from the members of the public. Radio has been found to be one of the most effective media for transforming a hither-to, under-developed society to a developed polity. Ojebode (2003) agrees with this line of thinking when he states that with few years of its emergence, the radio has metamorphosed from being an object of private concern, to a political and development instrument in the hands of government and NGOs. The information dispersing and the enlightenment role of the radio is the commonest of its functions. Asemah (2011) avers that the dissemination function of the radio covers information to people's alertness to health, agriculture, education, economy, politics, etc. Radio stations in Anambra State often relay special programmes that promote rural development. Thus, government a all levels - local, state and national utilise radio (and television) to mobilise support for its programmes. In recent time, the government of Anambra State led by Mr. Peter Obi has been using the radio as well as other media of information in the state to ferret information on security consciousness and alertness to the citizens.

The utilisation of radio for dissemination of rural related messages is not hundred percent faults free. The problems associated with it as chronicled by Asemah, Anum and Edegoh (2013, pp.28-31) include: i. communication related problems ii. Message related problem iii. Illiteracy iv. Use of English language by the electronic media v. Multiplicity of language in Nigeria vi. Lack of audience feedback vii. Ownership problem viii. Dearth of qualified personnel in Urban-centred development journalism x. Dearth of community based or vernacular radio telecommunication. In the same vein, Okoro (1998, p. 73) identifies the disadvantages associated with radio to include lack of visuals, no foreground or lack of background and the transient nature of radio messages.

\section{Methodology}

The study adopted survey research method. Survey is the most appropriate method of gathering and measuring data relating to demographics, attitude, opinion and perception (Asemah, Gujbawu, Ekhareafo and Okpanachi, 2012 cited in Edegoh, Asemah and Ude-Akpeh, 2013). A total of 740 copies of structured questionnaire were distributed to rural women in Idemili South Local Government Area of Anambra State. 
Idemili South L.G.A. is made up of Ojoto (the headquarters), Oba, Nnobi, Alor, Akwa-Ukwu, Awka-Etiti and Nneokwa. Based on the population of the towns, 110 respondents (from each town) were drawn from Ojoto, Oba, Nnobi and Alor giving a total of 440 respondents. And from the other three communities with lower population figures (Akwa-Ukwu, Awka-Etiti and Nneokwa) 300 respondents were drawn, 100 respondents from each of them. This gives a grand total of 740 respondents in all. Purposive sampling technique was used in the administration of instrument to respondents. Data obtained from the questionnaire was presented in frequency tables and simple percentage method was adopted in data analysis.

\section{Presentation of Findings}

Table 1: Return rate of Questionnaire

\begin{tabular}{|l|c|c|}
\hline Item & Frequency & Percentage \\
\hline Returned and found usable & 712 & 96 \\
\hline Not usable & 20 & 3 \\
\hline Not returned & 8 & 1 \\
\hline Total distributed & $\mathbf{7 4 0}$ & $\mathbf{1 0 0}$ \\
\hline
\end{tabular}

Table one shows that the return rate of questionnaire is $96 \%(\mathrm{n}=712)$ while the mortality rate is $4 \%(\mathrm{n}=28)$. The return rate is higher than the mortality rate. The mortality rate of $4 \%$ does not affect the study because it is insignificant compared to the return rate of $96 \%$. Thus, the copies were considered good enough to represent the population. The presentation and analysis of data that were obtained from the questionnaire were therefore based on the seven hundred and twelve (12) copies that were returned and found usable.

\section{Research Question One}

Do rural women in Idemili South Local Government Area of Anambra State, Nigeria, listen to radio?

Table 2: Provision of information on whether the rural women in Idemili South Local Government Area of Anambra State listen to radio.

\begin{tabular}{|l|c|c|}
\hline Response & Frequency & Percentage \\
\hline Yes & 608 & 85 \\
\hline No & 78 & 11 \\
\hline Don't know & 26 & 4 \\
\hline Total & 712 & 100 \\
\hline
\end{tabular}

Table two shows respondents' responses to the question "Do you listen to radio?" Data reveals that majority of the respondents $(85 \%, \mathrm{n}=608)$ listen to radio programme as they said yes to the question. However, $11 \%$ of the respondents $(n=78)$ disagreed, stating that they do not listen to radio programmes. Four percent of the respondents $(n=26)$ remained neutral. The implication of data on table two is that majority of the rural women studied listen to radio programmes.

Research Question Two

How often do the women in Idemili South Local Government Area of Anambra State, Nigeria, listen to radio?

Table 3: Provision of information on how often the respondents listen to radio programmes.

\begin{tabular}{|l|c|c|}
\hline Response & Frequency & Percentage \\
\hline Daily & 408 & 57 \\
\hline Weekly & 200 & 28 \\
\hline Rarely & 40 & 6 \\
\hline Don't know & 64 & 9 \\
\hline Total & 712 & 100 \\
\hline
\end{tabular}

Table three provides information on how often respondents listen to radio programmes. Fifty-seven percent of the respondents $(n=408)$ listen to radio programmes on daily basis, $28 \%$ of the respondents $(n=200)$ listen to radio on weekly basis and $6 \%$ of those sampled $(n=40)$ said they rarely listen to radio programmes. Nine percent of the respondents $(n=64)$ showed lack of knowledge of the question. The import of the data on table three is that out of the 608 respondents that listen to radio programmes, $408(57 \%)$ listen to radio pgorammes more often and $200(28 \%)$ of them do listen to radio programmes but not on regular basis. 
Radio Listening Habit of Rural Women in Idemili South Local Government Area of Anambra State, Nigeria.

\section{Research Question Three}

What type of radio programmes interest rural women in Idemili South Local Government Area of Anambra State, Nigeria?

Table 4: Provision of information on type of radio programmes that interest rural women in Idemili South Local Government Area of Anambra State, Nigeria.

\begin{tabular}{|l|c|c|}
\hline Response & Frequency & Percentage \\
\hline Agricultural programme & 242 & 34 \\
\hline Religious programme & 106 & 15 \\
\hline Health programme & 260 & 36 \\
\hline Entertainment/music programme & 34 & 5 \\
\hline Others & 70 & 10 \\
\hline Total & $\mathbf{7 1 2}$ & $\mathbf{1 0 0}$ \\
\hline
\end{tabular}

Table four presents the type of programmes that interest rural women in Anambra State. From the data on the table above, $34 \%$ of the respondents $(n=242)$ show interest in Agricultural programme, $15 \%(n=106)$ delight in religious programme while $36 \%(n=260)$ show more interest in health related programme. Entertainment $/$ music programme attract $5 \%$ (or $\mathrm{n}=34$ ) while other programmes such as radio drama, news and political programmes interest $10 \%$ (or $\mathrm{n}=70$ ) of the sampled population. Data on table four reveals that the programmes that interest rural women in Anambra State most (particularly in Idemili South) are health related programmes, Agricultural programmes and to some extent religious programmes.

\section{Research Question Four}

What gratifications do the rural women in Idemili South Local Government Area of Anambra State, Nigeria, derive from listening to radio programmes?

Table 5: Provision of information on gratifications derived by rural women in Idemili South Local Government Area of Anambra State, Nigeria.

\begin{tabular}{|l|c|c|}
\hline Response & Frequency & Percentage \\
\hline Agricultural issues & 210 & 29 \\
\hline Religious issues & 100 & 14 \\
\hline Health issues & 228 & 33 \\
\hline Social/Cultural/Political issues & 51 & 7 \\
\hline Family related issues & 80 & 6 \\
\hline Others & 43 & $\mathbf{1 0 0}$ \\
\hline Total & $\mathbf{7 1 2}$ & \\
\hline
\end{tabular}

Table five presents information on the gratifications that rural women derive from listening to radio programmes. As can be gleaned from data on the table above, the gratifications which rural women in Anambra State derive from listening to radio programmes are many and varied. Twenty-nine percent of the respondents $(n=210)$ derive gratifications relating to agriculture - improved seed plant, fertilizer procurement and proper utilisation techniques, poultry farm management and disease control methods, etc. Fourteen percent of the respondents hook on to the radio because they want to derive gratifications such as how to stay safe from diseases and how to manage hereditary diseases like diabetes, high blood pressure and rheumatism, among others; issues relating to child immunisation, maternal and antenatal care, etc. More still, $7 \%$ of the respondents $(n=51)$ derive socio cultural and political related gratifications while $11 \%(n=80)$ of those sampled obtain gratifications relating to family issues and $6 \%(\mathrm{n}=43)$ derive gratifications relating to other issues such as entertainment and relaxation.

\section{Discussion of Findings}

The findings show that rural women in Anambra State listen to radio programmes. This is attested to by an overwhelming majority of those sampled $(86 \%, n=608)$. This is in line with the submission of Nwabueze (2007) that radio is believed to be the most effective, popular and credible medium for reaching a large and heterogeneous audience. Findings of the study also show that a good number of the respondents listen to radio programmes regularly. Data analysis has shown that out of the 608 respondents that listen to radio programmes, 408 representing $57 \%$ listen to radio programmes on regular basis.

On the type of programmes that interest rural women, findings reveal that health related programmes come first, followed by agricultural programmes and religious programmes. Health, they say, is wealth and so, this finding is not surprising. Another finding made in this study is that rural women derive a lot of gratifications from listening to radio programmes. These gratifications are found to be many and varied. The prominent ones 
among these gratifications are located in the areas of health issues, agricultural issues and religious issues; in descending order of importance. This finding on the gratification that rural women derived from listening to radio is in tandem with the basic ideas of the uses and gratifications theory which we have reviewed in this study. Specifically, the finding confirms the assertion of Anaeto, Onabanjo and Osifeso (20089) that there are as many reasons for using the media as there are media users.

\section{Conclusion}

The study set out to investigate radio listening habit of rural women in Anambra State. Its main aims include to find out whether rural women listen to radio programmes, how often they do so, the radio programme that interest them most and the gratifications they derive from listening to radio programmes. Based on the findings of the study, we conclude that rural women in Anambra State do not only listen to radio but do so on regular basis. It is also safe for us to state that radio listening habit of rural women in Anambra State is both positive and encouraging. Based on the findings of the study, we recommend the following:

i. That a nation-wide study on radio listening habit of women be carried out as a way of reinforcing the finding of this study and to determine the effectiveness of radio as a potent force in mobilising women for national course. This is necessary to provide an adequate platform for women and to put an end to the contentious issue of women marginalisation particularly in politics.

ii. That all agencies involved in dissemination of information on health, agriculture and religion, among others intended for rural women (in particular) and rural dwellers (in general) should utilise the radio in doing so.

iii. That government should establish or assist capable individuals in establishing community based radio stations to adequately cover issues relating to rural community dwellers.

\section{References}

[1]. Acholonu, R. N. (2009). An assessment of the role of radio Nigeria Enugu national station in promoting political education am ong residents of Enugu metropolis in Ikpe, E. H., Kur, J. T. and Agudosy, F. I. (ed.). Perspectives on mass communication.: Michael Ibezimako Chukwu in memoriam. Enugu: Faba Communications (Nig.) pp. 61-77.

[2]. Anaeto, S. G., Onabanjo, O. S. and Osifeso, J. B. (2008). Models and theories of communication. Bowee, Maryland: African Renaissance Books Inc.

[3]. Asemah, E. S. (2010). Public relations and democratic governance in Nigeria: A componential overview. Lagos: Atsco Press.

[4]. Asemah, E. S. (2011). Selected mass media themes. Jos: University Press.

[5]. Asemah, E. S., Anum, V. and Edegoh, L. O. N. (2013). Radio as a tool for rural development in Nigeria. Prospects and challenges. International Journal of Arts and Humanities. Vol. 2 (1). pp.17-35

[6]. Asemah, E.S. and Edegoh, L. O. N. (2012). New media and political advertising in Nigeria: Prospects and challenges. African Research Review. Vol. 6(4). pp.248-265

[7]. Asemah, E. S., Gujbawu, M., Ekhareafo, D. O. and Okpanachi, R. (2012). Research methods and procedures in mass communication. Jos: Great Future Press

[8]. Daramola, J. (2002). Introduction to mass communication $\left(2^{\text {nd }}\right.$ ed.). Lagos: Rothan Press Ltd.

[9]. Edegoh, L. O. N. and Asemah, E. S. (2013). Attitude of Port Harcourt residents to advertisements in broadcast football programmes. Journal of Linguistic and Communication Studies. Vol. 3(1).

[10]. Edegoh, L. O. N., Nwanolue, I. and Eze, N. (2013). Audience assessment of the use of models in billboard advertising: A study of consumers of Amstel Malt in Onitsha, Nigeria. International Review of Social Sciences and Humanities. Vol. 6 No. 1

[11]. Edegoh, L. O. N., Asemah, E. S. and Ude-Akpeh, C. E. (2013). A study of HIV/AIDS media campaigns and knowledge of high risk factors among sex workers in South-South Nigeria. Research on Humanities and Social Sciences. Vol. 3 No. 13 pp. $98-106$.

[12]. Nwabueze, C. D. (2007). Environmental communication: Perspective on green communication and information management. Enugu; Daisy Press.

[13]. Ojebode (2003). "Radio as a development communication medium" in Soola, O. (ed.). Communication for development purpose. Ibadan: Craft Publications.

[14]. Okoro, N. (1998). The business of advertising. Enugu: Acena Publishers.

[15]. Okoro, N. and Agbo, B. (2003). Writing for the media society. Nsukka: Prize Publishers

[16]. Okunna, C. S. (1999). Introduction to mass communication (2 ${ }^{\text {nd }}$ ed.). Enugu: New Generation Books.

[17]. Onwuamalam, E. O. (2007). Radio-TV production. Owerri: Image Press. 